\title{
HUBUNGAN MOTIVASI DAN SIKAP DENGAN HASIL BELAJAR PADA MATA KULIAH KOMPUTER GRAFIS
}

\author{
Meldi Ade Kurnia Yusri \\ Email: ade.maky23@gmail.com \\ FIP Universitas Negeri Padang
}

\begin{abstract}
This research was motivated by the low student learning outcome at Curriculum and Technology of Education in Education of Sciences Faculty, State University of Padang. The purpose of this research was to reveal the relationship of learning motivation and learning attitudes with learning outcome of student TM 2013 semester 2 in KTP FIP UNP majors. This research used quantitative methods to the type of correlational research. The sample in this research were 77 students TM 2013 semester 2 in KTP FIP UNP majors, used Slovin formula with proportional random sampling technique. The research instrument was structured in the form of a questionnaire with Likert scale models, after being tested looking for validity and reliability. The data were analyzed using simple linear regression and multiple regression. The results showed that (1) There was a significant positive relationship between learning motivation and learning outcome of students TM 2013 semester 2 majoring in Curriculum and Educational of Technology at 0.492, (2) There was a significant positive relationship between the attitude of learning with learning outcome of students TM 2013 semesters 2 in Curriculum and Educational Technology majors by 0,646, (3) There was a significant positive relationship between learning motivation and learning attitude toward learning outcome for student TM 2013 semester 2 in Curriculum and Educational Technology majors at 0.702. Based on the findings of this study concluded that the two independent variables, namely learning motivation and learning attitude played a very important in improving learning outcome, in addition to other variables.
\end{abstract}

Keywords: Motivasi Belajar, Sikap Belajar, Hasil Belajar

\section{PENDAHULUAN}

Sistem pendidikan selalu berkembang dari waktu ke waktu sesuai dengan tuntutan yang terjadi dalam masyarakat. Tuntutan mengenai perkembangan pendidikan tersebut, tidak lepas dari akibat perkembangan peradaban manusia dan perkembangan masyarakat. Seperti halnya penerapan kurikulum pembelajaran yang selalu berkembang dari waktu ke waktu seiring dengan berkembangnya ilmu pengetahuan dan teknologi.

Faktor utama dalam proses pendidikan adalah peserta didik. Pendidikan diarahkan kepada peserta didik untuk dapat mengembangkan potensipotensi dasar peserta didik agar menjadi nyata. Agar terlaksananya tujuan pendidikan yang sesuai dengan peraturan dan perundangan, maka diperlukan suatu proses interaksi antara pendidik dengan peserta didik.

Pendidikan mempunyai peran yang sangat penting dalam mempersiapkan generasi muda yang dapat mengembangkan potensi diri yang mantap dalam menghadapi era globalisasi semenjak dari sekolah dasar hingga ke perguruan tinggi.

Universitas Negeri Padang merupakan salah satu lembaga pemerintah di kota Padang yang bergerak dalam bidang pendidikan tinggi. Semenjak didirikan pada tanggal 1 september 1954, Universitas Negeri Padang (UNP) telah mengalami banyak perubahan. Dalam sejarah perkembangannya, perubahan-perubahan yang terjadi bukan hanya meliputi nama dan tempat kedudukannya, akan tetapi juga status serta program-program pendidikan yang 
dikembangkannya, sesuai dengan kebijakan untuk memenuhi tuntutan perkembangan pendidikan di tanah air, seperti halnya Jurusan Kurikulum dan Teknologi Pendidikan FIP UNP.

Jurusan Kurikulum dan Teknologi Pendidikan FIP UNP merupakan jurusan yang menghasilkan lulusan sebagai tenaga pendidik dalam bidang teknologi informasi dan komunikasi. Kebutuhan akan teknologi informasi dan komunikasi sudah tidak terbantahkan lagi. Di mana hasil lulusan jurusan Kurikulum dan Teknologi Pendidikan FIP UNP sudah cukup banyak yang bekerja di bidangnya.

Pada kenyataannya, visi dan misi jurusan Kurikulum dan Teknologi Pendidikan FIP UNP belum dapat terpenuhi sebagaimana mestinya. Hal tersebut dikarenakan Jurusan Kurikulum dan Teknologi Pendidikan FIP UNP sendiri juga mengalami banyak permasalahan, baik internal maupun eksternal. Kesenjangan antara hasil pendidikan yang diperoleh oleh mahasiswa dengan tuntutan kebutuhan dalam kehidupan bermasyarakat dapat terlihat dari tingkat pengetahuan dan penguasaan keterampilan lulusan jurusan Kurikulum dan Teknologi Pendidikan FIP UNP yang masih belum sepadan dengan tuntutan dunia kerja. Masalah tersebut mengakibatkan jumlah lulusan jurusan Kurikulum dan Teknologi Pendidikan FIP UNP banyak yang menganggur dan kesulitan dalam mendapatkan pekerjaan sesuai dengan kompetensi ijazahnya. Hal ini disebabkan oleh masih rendahnya kualitas dalam proses belajar mengajar serta relevansi yang diajarkan dengan yang ada di lapangan. Hasil belajar dijadikan pedoman atau bahan pertimbangan dalam menentukan kemampuan mahasiswa. Oleh karena itu hasil belajar merupakan hal yang sangat penting dalam pendidikan dan dapat dipandang sebagai salah satu ukuran keberhasilan mahasiswa dalam pendidikan. Untuk itu, diperlukan berbagai macam upaya untuk meningkatkan hasil belajar.

Usaha untuk meningkatkan hasil belajar menuntut partisipasi berbagai pihak yang terkait agar mengarahkan perhatiannya kepada usaha meningkatkan mutu pendidikan. Meskipun
Pemerintah telah melakukan berbagai upaya peningkatan mutu pendidikan dalam berbagai aspek, namun pada kenyataannya kualitas pendidikan masih tetap rendah. Hal ini tercermin dari hasil belajar yang diperoleh mahasiswa jurusan Kurikulum dan Teknologi Pendidikan FIP UNP TM 2012 dalam mata kuliah Komputer Grafis.

Kenyataan ini dapat dilihat dari hasil pengamatan di lapangan. Fenomena yang berkaitan dengan rendahnya hasil belajar mahasiswa jurusan jurusan Kurikulum dan Teknologi Pendidikan FIP UNP diduga dipengaruhi oleh beberapa faktor, antara lain: (1) rendahnya motivasi belajar mahasiswa dalam mengikuti kegiatan perkuliahan, di mana hal ini dapat terlihat dari perilaku mahasiswa yang tidak bersemangat dalam mengikuti perkuliahan, perilaku mahasiswa yang sering terlambat, perilaku mahasiswa yang sering bolos dan perilaku mahasiswa yang tidak memiliki kemauan untuk mempelajari materi yang diajarkan oleh dosen, (2) rendahnya sikap mahasiswa dalam mengikuti perkuliahan, dimana hal ini dapat terlihat dari perilaku mahasiswa yang sering keluar masuk saat jam pelajaran, perilaku mahasiswa yang sering mengobrol dan meribut serta perilaku mahasiswa yang acuh tak acuh dan sibuk dengan kegiatan lain saat dosen menerangkan pelajaran.

Dalam proses pembelajaran, motivasi sangat diperlukan. Sebab seseorang yang tidak memiliki motivasi dalam belajar, tidak akan mungkin melakukan aktivitas belajar. Uno (2012:23) mengungkapkan motivasi dan belajar merupakan dua hal yang saling mempengaruhi. Motivasi berkaitan erat dengan prestasi dan hasil belajar siswa yang tinggi motivasinya, umumnya baik hasilnya, dan sebaliknya siswa yang rendah motivasinya rendah juga hasil belajarnya. Hal ini dimungkinkan dengan adanya motif-motif yang ada dalam diri siswa. Dengan adanya motif tersebut seorang siswa akan bergerak melakukan kegiatan belajarnya untuk mencapai keberhasilan yang diharapkan.

Uno (2012:27) mengungkapkan dalam kegiatan belajar motivasi mempunyai peranan penting, yaitu dalam (a) menentukan penguat 
belajar, (b) memperjelas tujuan, (c) menentukan ragam kendali terhadap rangsangan, (d) menentukan ketekunan belajar.

Peserta didik yang termotivasi dapat dilihat dari ciri-ciri yang ditampilkannya dalam kegiatan belajar. Slameto (1995) mengungkapkan bahwa motivasi dapat dilihat dari beberapa aspek. Aspek tertarik pada pengajar, mengendalikan perhatiannya terutama pada pengajar, tertarik pada mata pelajaran yang diajarkan, mempunyai antusias tinggi, ingin selalu bergabung dalam kelompok kelas, ingin identitasnya diakui, tindakan dan kebiasaan moralnya selalu dalam kontrol diri dan selalu terkontrol oleh lingkungan.

Motivasi merupakan faktor penggerak maupun dorongan yang dapat memicu timbulnya rasa semangat dan juga mampu merubah tingkah laku manusia atau individu untuk menuju pada hal yang lebih baik untuk dirinya sendiri. Sardiman (2010:75) mendefinisikan motivasi sebagai keseluruhan daya penggerak di dalam diri peserta didik yang menimbulkan kegiatan belajar, yang menjamin kelangsungan dari kegiatan belajar dan yang memberikan arah pada kegiatan belajar, sehingga tujuan yang dikehendaki oleh subjek belajar itu dapat tercapai. Motivasi adalah perubahan dalam diri atau pribadi seseorang yang ditandai dengan timbulnya perasaan dan reaksi untuk mencapai tujuan.

Keller (1987: 289-319) mengemukakan empat indikator dalam pembelajaran yang mempengaruhi motivasi peserta didik yaitu model pembelajaran ARCS (Attention, Relevance, Confidence, dan Satisfaction). Model pembelajaran ARCS merupakan suatu bentuk pendekatan pemecahan masalah untuk merancang aspek motivasi serta lingkungan belajar dalam mendorong dan mempertahankan motivasi peserta didik untuk belajar. Model pembelajaran ini berkaitan erat dengan motivasi peserta didik terutama motivasi untuk memperoleh pengetahuan yang baru. Sebagus apa pun rancangan bahan ajar, jika peserta didik tidak termotivasi maka tidak akan terjadi peristiwa belajar karena peserta didik tidak akan mempersepsi informasi dalam bahan ajar tersebut.

Di sisi lain, sikap belajar juga memiliki peranan penting dalam mempengaruhi pembelajaran. Bila sikap belajar positif, maka kegiatan intensitas belajar akan lebih tinggi. Bila sikap belajar negatif, maka akan terjadi hal yang sebaliknya. Sikap belajar yang positif dapat disamakan dengan minat. Minat akan memperlancar proses belajar peserta didik, karena belajar akan terjadi secara optimal dalam diri peserta didik apabila ia memiliki minat untuk mempelajari sesuatu. Peserta didik yang sikap belajarnya positif akan belajar dengan aktif.

Nasution (2010) berpendapat sikap belajar yaitu perasaan senang atau tidak senang, perasaan setuju atau tidak setuju, perasaan suka atau tidak suka terhadap pengajar, tujuan, materi dan tugastugas serta lainnya. Sikap belajar dapat diartikan sebagai kecenderungan perilaku ketika ia mempelajari hal-hal yang bersifat akademik. Perubahan sikap dapat diamati dalam proses pembelajaran, tujuan yang ingin dicapai, keteguhan, dan konsistensi terhadap sesuatu. Penilaian sikap adalah penilaian yang dilakukan untuk mengetahui sikap peserta didik terhadap mata pelajaran, kondisi pembelajaran, pendidik, dan sebagainya. Apabila sikap belajar yang ditunjukkan berwujud senang, maka akan timbul rasa ingin mengulang pelajaran, sebaliknya apabila sikap belajar yang ditunjukkan berwujud tidak senang, maka tidak akan timbul rasa ingin megulang pelajaran.

\section{METODE PENELITIAN}

Jenis penelitian yang dilakukan dalam penelitian ini adalah penelitian korelasional dengan menggunakan metode kuantitatif. Dalam penelitian ini, penulis meneliti hubungan motivasi belajar dan sikap belajar mahasiswa TM 2013 jurusan Kurikulum dan Teknologi Pendidikan FIP UNP.

Penelitian ini menggunakan dua variabel bebas yaitu (1) motivasi belajar (2) sikap belajar. Populasi dalam penelitian ini berjumlah 95, dengan 
jumlah sampel 77 dengan menggunakan rumus Slovin yang diambil dengan teknik proportional random sampling. Teknik pengumpulan data menggunakan angket atau kuesioner dengan skala Likert. Variabel motivasi belajar dan sikap belajar akan diberi alternatif jawaban masing-masing beserta skornya. Apabila jawaban yang diberikan merupakan pernyataan positif, maka akan diberi skor pada skala 5 sampai 1 , sebaliknya apabila pernyataan yang diberikan merupakan pernyataan negatif, maka akan diberi skor pada skala 1 sampai 5. Untuk lebih jelasnya, akan ditampilkan pada tabel 1. berikut:

Tabel 1. Alternatif jawaban tiap variabel beserta skornya

\begin{tabular}{|c|c|c|c|c|}
\hline No & Variabel & Jawaban & $(+)$ & $(-)$ \\
\hline \multirow[t]{5}{*}{1} & Motivasi & Selalu (SL) & 5 & 1 \\
\hline & & Sering (SR) & 4 & 2 \\
\hline & & Kadang-kadang (KD) & 3 & 3 \\
\hline & & Jarang (JR) & 2 & 4 \\
\hline & & Tidak Pernah (TP) & 1 & 5 \\
\hline \multirow[t]{5}{*}{2} & Sikap & Sangat Setuju (SS) & 5 & 1 \\
\hline & & Setuju (ST) & 4 & \\
\hline & & Ragu-ragu (RG) & 3 & 3 \\
\hline & & Tidak Setuju (TS) & 2 & \\
\hline & & Sangat Tidak Setuju (STS) & 1 & \\
\hline
\end{tabular}

Hasil uji validitas dan realibilitas terhadap butir pernyataan responden pada variabel motivasi belajar diperoleh dari 40 butir pernyataan yang terdapat pada angket motivasi belajar hanya 36 butir yang menunjukkan $\mathrm{r}>0.361$ (Valid), sedangkan 4 butir lainnya dinyatakan tidak valid karena koefisien korelasi $<0.361$. Nilai Cronbach's Alpha sebesar 0.902 .

Hasil uji validitas dan reliabilitas terhadap butir pernyataan responden pada variabel sikap belajar diperoleh dari 40 butir pernyataan yang terdapat pada angket sikap belajar hanya 36 butir yang menunjukkan $r>0.361$ (Valid), sedangkan 4 butir lainnya dinyatakan tidak valid karena koefisien korelasi $<0.361$. Nilai cronbach's alpha sebesar 0.891 .

Teknik analisis data yang digunakan untuk perhitungan statistik menggunakan program SPSS versi 17.00. Disamping itu diperoleh perhitungan statistik deskriptif seperti mean, standar deviasi, skor minimum, skor maksimum dan distribusi frekuensi.

\section{Statistik Data}

Pada bagian ini dianalisis pencapaian responden terhadap penyebaran kuisioner yang dilakukan, maka pada bagian deskripsi ini akan tergambar persentase dan kategori pencapaian responden tersebut. Untuk dilakukan dengan rumus yang dikemukaakan oleh Nana Sudjana (2009:29), sebagai berikut:

$$
T P=\frac{\text { Skor Rata-rata }}{\text { Skor Maksimum }} \times 100 \%
$$

Ket: $\mathrm{TP}=$ Tingkat pencapaian responden

Kriteria nilai tingkat pencapaian responden tersebut diklasifikasikan sebagai berikut :

$\begin{array}{ll}\begin{array}{l}\text { Persentase } \\ \text { Pencapaian } \\ 90 \%-100 \%\end{array} & \text { Kriteria } \\ & : \text { Baik Sangat } \\ 80 \%-89 \% & \text { : Baik } \\ 65 \%-79 \% & : \text { Cukup Baik } \\ 55 \%-64 \% & : \text { Kurang } \\ & \text { Baik } \\ 0 \%-54 \% & \text { : Tidak Baik }\end{array}$

\section{Pengujian Persyaratan Analisis}

\section{Uji Normalitas}

Uji normalitas untuk variabel Y. Uji normalitas dapat digunakan untuk melihat penyebaran data yaitu apakah data yang diperoleh berdistribusi normal atau tidak. Untuk melihat normalitas data, digunakan Kolmogorov Smirnov. Data dapat dikatakan berdistribusi normal apabila data memiliki nilai Asymp sig > 0,05.

\section{Uji Linearitas}

Bertujuan untuk mengetahui apakah model persamaan regresi antara variabel $(\mathrm{X})$ terhadap $(\mathrm{Y})$ bersifat linear atau tidak.

\section{Uji Multikolinearitas}


Uji multikolinearitas dilakukan untuk mengetahui apakah hubungan antara variabel bebas benar-benar independent. Pengujian multikolinearitas akan menggunakan variance inflation factor (VIF) dengan rumus sebagai berikut:

$$
V I F=\frac{1}{1-R^{2}}
$$

Apabila nilai VIF mendekati satu, berarti tidak terdapat multikolinearitas antara variabel independen. Apabila suatu variabel tidak berhubungan linear dengan beberapa variabel secara simultan $(\mathrm{R}=\mathrm{O})$, maka variabel tersebut akan memiliki VIF sebesar 1.

\section{Pengujian Hipotesis}

Hipotesis pertama dan kedua diuji dengan mengunakan korelasi dan regresi sederhana, dengan tujuan untuk melihat hubungan dan bentuk linearitas antara masing-masing variabel bebas $\mathrm{X} 1$ dan X2 dengan variabel terikat (Y), serta besarnya hubungan masing-masing variabel bebas (X) terhadap variabel terikat $(\mathrm{Y})$. Hipotesis ketiga diuji dengan menggunakan teknik korelasi dan regresi ganda, dengan tujuan untuk melihat hubungan dan bentuk garis regresi antara variabel bebas secara bersama-sama (X1.2) dengan variabel terikat (Y), serta besarnya hubungan masing-masing variabel bebas (X1.2) terhadap variabel terikat (Y).

\section{HASIL PENELITIAN DAN PEMBAHASAN}

Hasil dari perhitungan tingkat capaian responden pada variabel hasil belajar mahasiswa TM 2013 semester 2 jurusan Kurikulum dan Teknologi Pendidikan FIP UNP, diketahui rata-rata tingkat pencapaian skor hasil belajar adalah sebesar $81,49 \%$ dan termasuk pada kategori baik (Nana Sudjana, 2009:29).

Hasil dari perhitungan tingkat capaian responden pada variabel motivasi belajar, diketahui rata-rata tingkat pencapaian skor motivasi belajar adalah sebesar $76,87 \%$ dan termasuk pada kategori cukup baik (Nana Sudjana, 2009:29).

Hasil dari perhitungan tingkat capaian responden pada variabel sikap belajar (X2), diketahui rata-rata tingkat pencapaian skor sikap belajar adalah sebesar $82,47 \%$ dan termasuk pada kategori baik (Nana Sudjana, 2009:29).

Hasil analisis hipotesis pertama menunjukkan bahwa harga koefesien korelasi antara motivasi belajar dengan hasil belajar (rx1y) adalah sebesar $=0,492$ pada taraf signifikan (probabilitas nyata) sebesar $0,000<$ pada taraf signifikan $\alpha=0,05$. Dengan demikian Hipotesis (H1) yang menyatakan "Terdapat hubungan positif yang signifikan" dapat diterima. Dengan koefisien determinasi sebesar 0,242 , berarti motivasi belajar mempengaruhi hasil belajar sebesar $24,2 \%$ dengan persamaan regresi $\tilde{Y}=49,045+0,140 \mathrm{X} 1$, yang artinya bahwa apabila X1 naik satu satuan, maka $\tilde{Y}$ akan meningkat sebesar 0,140 satuan pada konstanta 49,045.

Berdasarkan temuan di atas, mahasiswa sebagai individu dalam perkembangannya tidak terlepas dari dorongan atau hasrat ingin mempelajari sesuatu baik itu berasal dari diri mahasiswa pribadi maupun pengaruh dari luar yang memacu mahasiswa untuk belajar. Temuan ini sesuai dengan yang disampaikan Uno (2012:27) bahwa dalam kegiatan belajar motivasi mempunyai peranan penting, yaitu dalam (a) menentukan penguat belajar, (b) memperjelas tujuan, (c) menentukan ragam kendali terhadap rangsangan, (d) menentukan ketekunan belajar. Sama halnya dengan yang diungkapkan Sardiman (2010:75) yang mendefinisikan motivasi sebagai keseluruhan daya penggerak di dalam diri peserta didik yang menimbulkan kegiatan belajar, yang menjamin kelangsungan dari kegiatan belajar dan yang memberikan arah pada kegiatan belajar, sehingga tujuan yang dikehendaki oleh subjek belajar itu dapat tercapai.

Hasil analisis hipotesis kedua menunjukkan bahwa harga koefesien korelasi antara sikap belajar dengan hasil belajar (rx2y) adalah sebesar $=0,646$ pada taraf signifikan (probabilitas nyata) sebesar $0,000<$ pada taraf signifikan $\alpha=0,05$. Dengan demikian Hipotesis (H1) yang menyatakan "terdapat hubungan positif yang signifikan antara sikap belajar terhadap hasil belajar mahasiswa TM 2013 semester 2 jurusan 
Kurikulum dan Teknologi Pendidikan FIP UNP" dapat diterima. Dengan koefisien determinasi sebesar 0,417 , berarti sikap belajar mempengaruhi hasil belajar sebesar $41,7 \%$ dengan persamaan regresi $\tilde{Y}=34,680+0,235 \mathrm{X} 2$. Yang artinya bahwa apabila X2 naik satu satuan, maka $\tilde{Y}$ akan meningkat sebesar 0,235 satuan pada konstanta 34,680 .

Semangat belajar itu juga tidak lengkap apabila mahasiswa tidak menyikapi belajar dengan baik, karena itu sikap belajar mahasiswa juga sangat berpengaruh terhadap pencapaian tujuan belajar. Hal ini sesuai dengan yang disampaikan Nasution (2010) bahwa sikap belajar merupakan perasaan senang atau tidak senang, perasaan setuju atau tidak setuju, perasaan suka atau tidak suka terhadap pengajar, tujuan, materi dan tugas-tugas serta lainnya. Sehingga bila sikap belajar positif, maka kegiatan intensitas belajar akan lebih tinggi. Sebaliknya bila sikap belajar negatif, maka kegiatan intensitas belajar akan lebih rendah.

Hasil analisis hipotesis ketiga menunjukkan bahwa harga koefesien korelasi antara motivasi belajar dan sikap belajar dengan hasil belajar (rx1.2y) adalah sebesar $=0,702$ pada taraf signifikan (probabilitas nyata) sebesar $0,000<$ pada taraf signifikan $\alpha=0,05$. Dengan demikian Hipotesis (H1) yang menyatakan "Terdapat hubungan motivasi belajar dan sikap belajar terhadap hasil belajar mahasiswa TM 2013 semester 2 jurusan Kurikulum dan Teknologi Pendidikan FIP UNP" dapat diterima. Dengan koefisien determinasi sebesar 0,492, berarti motivasi belajar, sikap belajar secara bersama-sama mempengaruhi hasil belajar sebesar 49,2\% dengan persamaan regresi $\tilde{Y}=28,832+0,084 \times 1+0,196$ $\mathrm{x} 2$. Yang artinya bahwa apabila X1 dan X2 naik satu satuan, maka $\tilde{Y}$ akan meningkat sebesar 0,084 satuan untuk motivasi belajar dan 0,196 untuk sikap belajar pada konstatanta 28,832 .

Untuk mengetahui sumbangan efektif dari masing-masing prediktor, maka dilakukan analisis regresi ganda. Dari hasil analisis, diperoleh hasil: (1) Sumbangan efektif dari prediktor sikap belajar dan motivasi belajar secara bersama-sama adalah
49,2\%, berdasarkan hasil $R^{2}=0,492$. (2) Sumbangan efektif dari prediktor sikap belajar adalah $41,7 \%$, berdasarkan hasil $R^{2}=0,417$. (3) Sumbangan efektif dari prediktor motivasi belajar adalah 7,5\%. Dengan demikian dapat dilihat bahwa sumbangan efektif terbesar dalam memprediksi hasil belajar diperoleh dari sikap belajar, yaitu $41,7 \%$. Sedangkan sumbangan relatif dari prediktor sikap belajar dan motivasi belajar secara bersamasama adalah $84,76 \%$.

\section{SIMPULAN DAN SARAN \\ Simpulan}

Berdasarkan temuan-temuan yang diperoleh dalam penelitian ini, maka dapat diambil kesimpulan sebagai berikut:

1. Dari hasil perhitungan tingkat capaian responden pada variabel hasil belajar mahasiswa TM 2013 semester 2 jurusan Kurikulum dan Teknologi Pendidikan FIP UNP, diketahui rata-rata tingkat pencapaian skor hasil belajar adalah sebesar $81,49 \%$ dan termasuk pada kategori baik.

2. Dari hasil perhitungan tingkat capaian responden pada variabel motivasi belajar mahasiswa TM 2013 semester 2 jurusan Kurikulum dan Teknologi Pendidikan FIP UNP, diketahui rata-rata tingkat pencapaian skor motivasi belajar adalah sebesar $76,87 \%$ dan termasuk pada kategori baik.

3. Dari hasil perhitungan tingkat capaian responden pada variabel sikap belajar mahasiswa TM 2013 semester 2 jurusan Kurikulum dan Teknologi Pendidikan FIP UNP, diketahui rata-rata tingkat pencapaian skor sikap belajar adalah sebesar $82,47 \%$ dan termasuk pada kategori baik

4. Motivasi belajar memiliki hubungan yang berarti dengan hasil belajar mahasiswa TM 2013 semester 2 jurusan Kurikulum dan Teknologi Pendidikan FIP UNP sebesar 0,492. Hal ini berarti semakin tinggi motivasi belajar, maka semakin baik pula hasil belajar mahasiswa dalam mata kuliah Komputer Grafis. Lalu apabila dilakukan pengontrolan 
terhadap variabel lain dalam hal ini motivasi belajar, maka diperoleh hubungan yang signifikan antara motivasi belajar dengan hasil belajar.

5. Sikap belajar memiliki hubungan yang berarti dengan hasil belajar mahasiswa TM 2013 semester 2 jurusan Kurikulum dan Teknologi Pendidikan FIP UNP sebesar 0,646. Hal ini berarti semakin baik sikap belajar mahasiswa maka semakin baik pula hasil belajar mahasiswa dalam mata kuliah Komputer Grafis. Lalu apabila dilakukan pengontrolan terhadap variabel lain dalam hal ini sikap belajar, maka diperoleh hubungan yang signifikan antara sikap belajar dengan hasil belajar.

6. Motivasi belajar dan sikap belajar secara bersama-sama memiliki hubungan yang berarti dengan hasil belajar mahasiswa TM 2013 semester 2 jurusan Kurikulum dan Teknologi Pendidikan FIP UNP sebesar 0,702. Hal ini berarti semakin baik motivasi belajar dan sikap belajar secara bersama-sama, maka semakin baik juga hasil belajar mahasiswa dalam mata kuliah Komputer Grafis. Apabila dilihat dari gambar persamaan garisnya dapat dilihat bahwa sebaran data secara keseluruhan mendekati garis dan tidak ada sebaran data yang terlalu jauh dari garis, dimana hal tersebut membuktikan bahwa hubungan motivasi belajar dan sikap belajar secara bersama-sama linear dengan hasil belajar.

\section{Saran}

Berdasarkan temuan yang diperoleh dalam penelitian ini, maka dikemukakan saran-saran sebagai berikut:

1. Ketua Labor KTP FIP UNP, agar dapat lebih meningkatkan fasilitas labor yang akan digunakan mahasiswa untuk belajar demi membuat kelas yang menyenangkan dan membangkitkan motivasi belajar mahasiswa dalam belajar di labor.

2. Dosen mata kuliah agar dapat memberikan yang terbaik untuk mahasiswa khususnya dalam hal memberikan semangat dan membangkitkan rasa ingin tahu mahasiswa terhadap materi yang dibahas, sehingga memicu mahasiswa untuk semangat dan senang dalam mengikuti perkuliahan, di mana yang tadinya bersikap acuh tak acuh menjadi senang dan betah berada di kelas.

3. Mahasiswa agar menyadari bahwa motivasi dan sikap dalam pelajaran akan berpengaruh pada hasil belajar, artinya semakin baik motivasi dan sikap belajar mahasiswa maka akan semakin baik pula hasil belajar yang akan diperoleh, contoh: sikap mahasiswa yang tidak serius dalam belajar akan berbeda hasil belajarnya dengan mahasiswa yang serius dalam belajar.

4. Perlu dilakukan penelitian lanjutan untuk mengungkapkan faktor-faktor yang ikut menentukan hasil belajar mahasiswa. Hasil penelitian ini juga dapat digunakan sebagai salah satu referensi untuk para peneliti lainnya dalam rangka untuk meneliti faktor-faktor lain yang belum sempat diteliti dalam penelitian ini.

\section{DAFTAR PUSTAKA}

Ahmad Fauzi. 2008. Psikologi Umum. Bandung: CV Pustaka Setia.

Dimyati dan Mudjiono. 2009. Belajar dan Pembelajaran. Jakarta: Rineka Cipta.

Hamzah B. Uno. 2007. Motivasi dan Pengukurannya. Jakarta: PT. Bumi Aksara 2012.Teori Motivasi dan Pengukurannya. Jakarta: PT. Bumi Aksara

M. Keller, John. (1987). "Development and Use of The ARCS Model of Instructional Design". Jurnal of Instructional Development.

Nana Sudjana. 1989. Teori-Teori Belajar Untuk Pengajaran. Jakarta:UI Press

Bandung: Remaja Rosdakarya

$$
\text { 2009. Media Pengajaran. }
$$

$$
\text { 2011. Dasar-Dasar Proses }
$$

Belajar Mengajar. Bandung: Sinar Baru Algensindo. 
S. Nasution. 2010. Orientasi Pembelajaran Jakarta: Mitra Utama

Sardiman. 2010. Interaksi dan Motivasi Siswa Belajar Mengajar. Jakarta: Raja Grafindo Persada
Slameto. 1995. Faktor-faktor yang mempengaruhi belajar mengajar. Jakarta: Rineka Cipta.

. 2003. Belajar dan Faktor yang Mempengaruhi. Jakarta: Rineka Cipta 